\title{
Nigeria's industrial development: issues and challenges in the new millennium
}

\author{
D. D. Ajayi \\ Department of Geography, University of Ibadan, Nigeria
}

\begin{abstract}
Perhaps one major problem facing Nigeria today that has received little or no attention remains her low industrial base. Indeed, apart from South Africa and Egypt, both of which are outside tropical Africa, the contribution of manufacturing to the economy of Nigeria, places Nigeria far behind the Newly Industrializing Countries (NICs) of the South East Asia. Manufacturing in Nigeria has largely been dominated by a valorization of raw materials and import-substitution type that are capital intensive rather than labour intensive. In addition, the absence of heavy industries and car manufacturing has militated against effective transfer of technology hence the heavy investment in manufacturing. There is the general low level of inter-industry linkages-failure on the part of industries to utilize the products/by-products of other industries especially in the production process. Studies on manufacturing in Nigeria have focused on small-scale industries and some behavioral aspects of manufacturing at the regional level. In some cases, explanations have been offered in terms of factor endowments. The last three or four decades have largely witnessed a reorientation in industrial geography and especially in a globalizing economy whereby a lot of emphasis is placed on inter-industry linkages, and especially networks of production subcontracting in the development of industrial activities and the economy as a whole. This paper thus seeks to examine the extent to which Nigeria's manufacturing has been affected by inter-industry linkages, and especially production subcontracting, and the challenges for Nigeria's manufacturing/industrial development in the new millennium.

Keywords: import-substitution, valorization, privatization, commercialization, inter-industry linkages, production subcontracting.
\end{abstract}




\section{Introduction}

Nigeria remains a major industrial country in the West African sub-region and Africa south of the Sahara. Although, few studies have focused on manufacturing activities within the country, most of these have largely focused on some aspects of manufacturing especially at the regional level, small-scale industries and local crafts. Perhaps, Schatzl [1] Ayeni [2, 3]; Mabogunje [4] studies on the spatial pattern of manufacturing provide a good starting point on detailed studies of manufacturing in Nigeria. The consensus is that manufacturing is concentrated in a few cities, and especially the state capitals. These concentrations have usually been explained in terms of specific principles of industrial development. With little attention given to the emerging pattern despite the changing phases of manufacturing and industrial development policies. From mere crafts works in the earliest time to valorization of raw materials through import substitution to local sourcing of industrial raw materials in recent times. In addition, the absence of heavy industries and car manufacturing has militated against effective transfer of technology hence the heavy investment in manufacturing has led to a relative neglect of other sectors of the economy, especially agriculture. There is the general low level of interindustry linkages While several studies on production subcontracting have been conducted in the western world, especially the United States of America and Great Britain, studies on industrialization in Nigeria, have largely focused on the examination and analysis of single components of industrial activity or the spatial distribution and development of manufacturing industries. Other studies have focused on the nature and characteristics of small-scale industries and some behavioral aspects of manufacturing at the regional level. In some cases, explanations have been offered in terms of factor endowments.

As a precursor, this paper presents a holistic view of the industrial development of Nigeria with particular emphasis on to the spatial pattern, the temporal trend, and the extent to which industrial development in the country has been influenced by contemporary globalization of industrial activities. Globalization here is viewed with specific reference to industrial production subcontracting, an emerging strategic industrial production technique integrating the world industrial development. Contemporary thinking in industrial geography and especially in a globalizing economy places a lot of emphasis on inter-industry linkages, and especially networks of production subcontracting in the development of industrial activities and the economy as a whole. The paper seeks to examine (i) the extent to which Nigeria's manufacturing has improved over the years? (ii) what factors have been responsible (if any) for this improvement? (iii) what is the extent of inter-industry linkages, and especially production subcontracting in Nigeria's manufacturing, and (iv) what are the challenges for Nigeria's manufacturing/industrial development in the new millennium? In addition, the paper takes a look at the issues of privatization and commercialization of industrial concerns. 


\section{Industrial development experience in Nigeria}

The growth in industrial activities discussed in this section is in three phases. These are the pre-colonial era; early post-colonial era; and events since the mid1980s.

\subsection{Pre-colonial era}

The pre-colonial era, that is, the pre-1900 economy of Nigeria featured considerable craft industries in the various clans and kingdoms; modern factory activity was then hardly known (Onyemelukwe [5]). Prominent among these craft industries that featured in local and inter-regional trade, were artifacts of wood, brass and bronze, leather, hand woven textiles and bags, iron workings and fire burnt pottery from local clay. The various zones specialized in different crafts closely linked with the available raw materials

However, the crafts industry has declined considerably following the superior competition from modern industrial activities, particularly manufacturing. Onyemelukwe [5] notes that Nigeria has embraced the factory type industrialization as the main panacea to her underdevelopment. The coming of Europeans, especially in the wake of formal trade contact, brought about the first widely recognized forms of modern industrialization. Slave trade yielded priority of place to "legitimate trade" (Flint [6]), in industrial raw materials obtainable in this part of West Africa. The need then arose for valorization (Aboyade [7]; Mabogunje [8]; Ayeni [2]; Onyemelukwe [5]). Considerable finishing operations including printing and publishing, baking and furniture works, also featured from the beginning. Whereas processing was geared towards the rapidly expanding export trade on a relatively large scale, the finishing operations served only to meet domestic demand, which was then relatively small and geographically localized. However, the Nigerian industrial scene changed after the end of the Second World War, in at least two respects (Adegbola [9]; Onyemelukwe [5]) with respect to the traditional demand from Europe for industrial raw materials following the post war reconstruction needs and global resumption of full-scale activity in trade and industry, and the post war economic boom in raw material export and a sharp rise in the general purchasing power and investment potential of indigenous businessmen brought about growth in the number of manufacturing establishments.

The transformation in the Nigerian economy during the post war years was faced with low level of technology and the small size of the available indigenous manpower thus industrial development involved the assembly-type pattern of import substitution. Full-scale industrialization involving the production of basic capital goods could not be embarked upon. The gradual assumption of political decision-making power by Nigerians during the 1950s enhanced the substitution of capital goods import or raw material imports for consumers' goods. Onyemelukwe [5] notes that of the 47 industrial establishments in the country in the pre-1947 period, 21(44.71 per cent) were engaged in processing activities. The remaining 26 (55.3 per cent) establishments were engaged in the finishing 
aspects of manufacturing. Out of the 26, as many as 15 (31.9 per cent) establishments were small printing works and bakeries. All these had the bulk of their patronage among the few foreign (mainly European) administrators, missionaries and merchants.

\subsection{Early post-colonial era}

The post-colonial era was characterized by vigorous import substitution and the beginning of decline for the export-oriented processing of raw materials. The policy of import substitution, which was meant to reduce dependence on foreign trade and save foreign exchange however led in the direction of mere assemblage of foreign, produced items rather than manufacturing per se. At independence, there were only about 150 plants of medium and large scale size in the industrial sector majority of which were established in the late 1950s. By 1965, however, the number of medium and large scale firms had risen to 380 arising from the intensification of the process of import substitution and the establishment of firms to undertake domestic manufacture of goods hitherto imported, though still largely dominated by low technology light industries. Items manufactured include food, beverages and tobacco. The engineering sector was dominated by metal furniture and fixtures, structural metal products and fabricated metals.

The manufacture of agricultural and special industrial machinery and equipment, household apparatus, and transport equipment share of value added was quite low. (see Teriba et al. [10]). This growth in manufacturing however witnessed a period of lull following the political crisis, which culminated in the civil war until the early 1970s. As a part of the reconstruction efforts, the Second National Development Plan, 1970-74, which had the objectives of a united, strong and self-reliant nation; a great and dynamic society; a just and egalitarian society; a land of bright and full employment for all citizens; and a free and democratic society, had as its major policy thrust: to promote even development and fair distribution of industries in all parts of the country; ensure a rapid expansion and diversification of the industrial sector of the economy; increase the incomes realized from manufacturing activity; create more employment opportunities. Others include: to promote the establishment of industries which cater for overseas markets in order to earn foreign exchange; continue the programme of import-substitution, as well as raise the level of intermediate and capital goods production; initiate schemes designed to promote indigenous manpower development in the industrial sector; and raise the proportion of indigenous ownership of industrial investments.

In order to do these, the government laid down priorities and initiated measures to achieve them such as reconstructing damaged industrial capacities, the promotion of expansion of the intermediate and capital good industries in order to raise the contribution of value added in the manufacturing sector, and the promotion of rapid industrial development etc. The situation continued in this manner to the mid-1980s. 


\subsection{Events since mid-1980s}

The industrial sector of the Nigerian economy improved over the years. The relative share of manufacturing industry in the GDP increased from 19.8 per cent in 1966/67 to 32.4 percent in 1971/72 (Teriba and Kayode [11]). However, the manufacturing sector has witnessed considerable decline since the mid-1980s. For instance, Table 1 shows that the percentage share of manufacturing in Nigeria's gross value added decreased from about 17 per cent in the early $1980 \mathrm{~s}$ to 13 per cent in 1987 , and 10.7 per cent in 1993 and 12.1 per cent in 1994 . The share of manufacturing in the GDP decreased from 9.2 per cent in 1981 to 6.8 percent in 1987, 5.5 per cent in 1993 and hovered around 6.0 per cent in the years between 1994 and 2002. The number of industrial establishments which increased from 421 in 1964 to 1,293 in 1975, and 2,360 in 1989, decreased to 1,891 in 1993 .

The number of industrial employees which increased from 64,965 in 1964 to 93,270 in 1969 (excluding eastern region) decreased to 27102 in 1989 but increased again to 244,243 in 1985 (Schatzl, [1]; FOS, [12]; Federal Ministry of Industries [13]; MAN [14]). Nigeria's manufacturing consists largely of assembly plants with little or no backward linkage in the economy. This is because the bulk of inputs were imported (Schatzl [1]; Corfrey et al. [15]; Ayeni [2]). The few industries that have any form of backward linkage are 'rooted' industries such as tin smelting in Jos, timber and plywood factories at Sapele, and cement factories at Ewekoro and Sagamu. Most industrial activities were linked to industries in foreign countries both for the final consumption goods and intermediate products (Nwafor [16]; Adegbola [9]).

Table 1: $\quad$ Some aspects of Nigeria's manufacturing, 1981-2002 (at current prices).

\begin{tabular}{cccccc}
\hline Year & $\begin{array}{c}\% \text { of Total } \\
\text { Value }\end{array}$ & $\begin{array}{c}\% \text { of } \\
\text { GDP }\end{array}$ & Year & $\begin{array}{c}\text { \% of Total } \\
\text { Value } \\
\text { Added }\end{array}$ & $\begin{array}{c}\% \text { of } \\
\text { GDP }\end{array}$ \\
1981 & 17.0 & 9.2 & 1992 & 10.0 & 4.8 \\
1982 & 17.3 & 9.6 & 1993 & 10.7 & 5.5 \\
1983 & 17.1 & 10.0 & 1994 & 12.1 & 6.6 \\
1984 & 14.8 & 7.8 & 1995 & N/A & 6.6 \\
1985 & 16.4 & 8.7 & 1996 & N/A & N/A \\
1986 & 16.2 & 8.7 & 1997 & N/A & N/A \\
1987 & 13.0 & 6.8 & 1998 & N/A & 5.9 \\
1988 & 14.3 & 7.5 & 1999 & N/A & 6.0 \\
1989 & 10.5 & 5.3 & 2000 & N/A & 6.0 \\
1990 & 10.9 & 5.5 & 2001 & N/A & 6.2 \\
1991 & 11.9 & 5.9 & 2002 & N/A & 6.0 \\
\hline
\end{tabular}

Source: $\quad$ Federal Office of Statistics: National Accounts of Nigeria, 1981 to1994; CBN-Annual Report and Statement of Accounts, 2003.

The Structural Adjustment Programme (SAP) was in part adopted in July 1986 to redress the prevailing industrial scenario (Ukwu [17]) which apparently pushed capacity utilization up from 30 per cent at the end of 1986 , to 36.7 per 
cent by mid-1987 (MAN [18]), 40.3 per cent in 1990, 42.0 per cent in 1991 and 41.8 per cent in 1992 but witnessed a decrease to 29.3 per cent in 1995 and 32.5 per cent in 1996 (Nigeria [19]). However, the situation deteriorated for some highly import dependent industries like electrical/electronics, basic metal, iron and steel, and vehicle assembly where capacity utilization has fallen below 10 per cent (Ajayi [20]). A recent survey of manufacturing industries by the Central Bank of Nigeria [21] shows that capacity utilization rate increased to 46.2 per cent in 2002. Although, average capacity utilization rate increased in Lagos area, Enugu, and Bauchi zones to 59.1, 51.1 and 35.5 percent respectively but declined in Kano and Ibadan zones to 42.6 and 43.0 per cent respectively. Some industries now obtain raw materials locally within Nigeria. For instance, the level of local sourcing of materials in selected industrial sectors between 1987 and 1989 is shown in Table 2.

Table 2: Level of local sourcing (\%) of raw materials in Nigeria, 1987-1989.

\begin{tabular}{|c|c|c|c|c|}
\hline Industry Group & $\begin{array}{c}\text { Jan-Jun } \\
1987\end{array}$ & $\begin{array}{l}\text { Period } \\
\text { Jun-Jul } \\
1988\end{array}$ & $\begin{array}{l}\text { Jun-Dec } \\
1988\end{array}$ & $\begin{array}{l}\text { Jan-Jun } \\
1989\end{array}$ \\
\hline $\begin{array}{l}\text { Food, Beverages } \\
\text { and Tobacco }\end{array}$ & 65.2 & 62.7 & 63.0 & 62.0 \\
\hline $\begin{array}{l}\text { Wood and Wood } \\
\text { Products (Including }\end{array}$ & & & & \\
\hline $\begin{array}{l}\text { furniture) } \\
\text { Non-metallic }\end{array}$ & 7.6 & N.A & N.A & N.A \\
\hline $\begin{array}{l}\text { Mineral products } \\
\text { Textiles, Wearing }\end{array}$ & 76.5 & 88.4 & 85.0 & 81.0 \\
\hline $\begin{array}{l}\text { Apparel and Leather } \\
\text { Chemicals and }\end{array}$ & 52.4 & 52.5 & 57.0 & 62.0 \\
\hline $\begin{array}{l}\text { Pharmaceuticals } \\
\text { Domestic and }\end{array}$ & 31.5 & 36.3 & 63.0 & 37.0 \\
\hline $\begin{array}{l}\text { Industrial Plastic } \\
\text { and Rubber } \\
\text { Basic metal, Iron } \\
\text { and Steel and }\end{array}$ & 20.6 & 53.0 & 48.0 & 45.0 \\
\hline $\begin{array}{l}\text { fabricated metal } \\
\text { products } \\
\text { Motor vehicles and }\end{array}$ & 49.7 & 39.7 & 30.0 & 30.0 \\
\hline $\begin{array}{l}\text { Miscellaneous } \\
\text { assembly }\end{array}$ & 21.8 & N.A & N.A & N.A \\
\hline $\begin{array}{l}\text { Electrical/Electronics } \\
\text { Pulp, Paper and paper } \\
\text { products, printing }\end{array}$ & 19.3 & N.A & N.A & 10.0 \\
\hline and publishing & 13.7 & 15.7 & 42.0 & 46.0 \\
\hline Average & 42.8 & 49.7 & 52.0 & 46.0 \\
\hline
\end{tabular}

Sources: Adapted from Ajayi (1998).

The revitalization of the industrial sector to promote the development of other sectors and the entire economy has attracted a major consideration in the National Rolling Plans, as policy objectives include the achievement of maximum growth in investment and output, and expansion of employment. An 
average growth rate of $0.8 \%$ was projected in the First Rolling Plan (1990-1992) for this sector. This was expected to increase its share of the GDP to slightly over these targets and expected to be achieved through improvement in capacity utilization in existing industries and increased investment in new ones, as well as more effective implementation of relevant policy - reform measures. These policy measures include strengthening administrative machinery, implementation of the privatization and commercialization policy, local sourcing of material raw materials, and the promotion of Small-scale industries [Federal Republic of Nigeria [19]], but generally lacking in strategies to achieve the set objectives.

\section{Spatial pattern of industrialization}

The spatial pattern of industries discussed here pertains to the number of firms as found in the various locations within the country. Although, earlier studies have confirmed that manufacturing activities in Nigeria are concentrated in a few states and primarily in a few cities, which are mainly, state capitals, ports and major administrative centres (Schatzl [1]; Mabogunje [8]; Adegbola [9]; Onyemelukwe [22]; Ayeni [2]). Thus, there are spatial disparities in the distribution of industrial establishments. Ajaegbu [23] has shown four industrialurban conurbations in Nigeria. These are: Lagos-Ibadan, the Kano-KadunaZaria-Jos, Benin-Sapele-Warri, and Port-Harcourt-Aba-Onitsha-Enugu conurbations.

This spatial disparity in the distribution of manufacturing activities have often been explained in terms of the need for the valorization of raw agricultural products or the treatment of raw materials for export, or through the principle of import substitution adopted by the Nigerian governments as their industrial planning strategy (Ayeni [2]). The result of valorization means the establishment of manufacturing industries in areas where natural resources such as agricultural products and minerals are found [Abiodun and Aguda [24]]. In spite of the successive development plans aimed at even distribution of industrial activities in all parts of Nigeria, industrial activities are still concentrated in a few locations (see Table 3 ).

The pattern of the distribution of manufacturing industries at the city level in 1989 indicates that there is a marked concentration of manufacturing establishments in the southern part of the country, and especially Lagos in the southwest. The leading position of Lagos in the southwest is clearly shown by the size of the proportional circle. Other locations of relative high concentration of industrial establishments are Kano in the North; Ibadan and Benin in the southwest; Enugu and Port-Harcourt in the southeast. While manufacturing establishments are concentrated in several locations in the south, they are found in a few locations in the north. This industrial concentration is further reflected, and has thus form the basis for the choice of the Lagos region for Ajayi [20, 2530] works on industrial linkages within the Lagos region, and with other parts of the country. 
Table 3: $\quad$ Manufacturing industries in Nigeria, 1989.

\begin{tabular}{|c|c|c|c|c|c|c|c|}
\hline $\mathrm{S} / \mathrm{No}$ & State & $\begin{array}{l}\text { No. of } \\
\text { Estabs. }\end{array}$ & $\begin{array}{l}\% \\
\text { of Total }\end{array}$ & $\mathrm{S} / \mathrm{No}$ & State & $\begin{array}{l}\text { No. of } \\
\text { Estabs. }\end{array}$ & $\begin{array}{l}\% \\
\text { of Total }\end{array}$ \\
\hline 1. & Abia & 0 & 0.0 & 16. & Katsina & 8 & 0.3 \\
\hline 2. & Adamawa & 5 & 0.2 & 17. & Kebbi & 0 & 0.0 \\
\hline 3. & Akwa Ibom & 40 & 1.7 & 18. & Kogi & 12 & 0.5 \\
\hline 4. & Anambra & 101 & 4.3 & 19. & Kwara & 33 & 1.4 \\
\hline 5. & Bauchi & 8 & 0.3 & 20. & Lagos & 768 & 32.6 \\
\hline 6. & Benue & 37 & 1.6 & 21. & Niger & 17 & 0.7 \\
\hline 7. & Borno & 33 & 1.4 & 22. & Ogun & 71 & 3.0 \\
\hline 8. & Cross River & 59 & 2.5 & 23. & Ondo & 34 & 1.4 \\
\hline 9. & Delta & 88 & 3.7 & 24. & Osun & 20 & 0.8 \\
\hline 10. & Edo & 121 & 5.1 & 25. & Oyo & 90 & 3.8 \\
\hline 11. & Enugu & 84 & 3.6 & 26. & Plateau & 46 & 2.0 \\
\hline 12. & Imo & 171 & 7.3 & 27. & Rivers & 212 & 9.0 \\
\hline 13. & Jigawa & 0 & 0.0 & 28. & Sokoto & 17 & 0.7 \\
\hline 14. & Kaduna & 42 & 1.8 & 29. & Taraba & 19 & 0.8 \\
\hline \multirow[t]{3}{*}{15.} & Kano & 216 & 9.2 & 30. & Yobe & 2 & 0.08 \\
\hline & & & & 31. & FCT & 1 & 0.04 \\
\hline & & & & & Total & 2,355 & 100.0 \\
\hline
\end{tabular}

Source: Federal Ministry of Industries-Abuja cited in Ajayi [20].

\section{Recent trends in Nigeria's industrial development}

The section focuses on networks of industrial linkages as occasioned by industrial production subcontracting (a strategic positioning of industrial activities), and privatization in Nigeria industrial development.

\subsection{Industrial production subcontracting experience}

The Nigeria's experience shows that production subcontracting linkages started in the early 1960s, the post-independence period. The earliest stage in the adoption of production subcontracting as an industrial production technique in Nigeria was characterized by insignificant growth, and a rapid growth thereafter. However, there was marked variation in the adoption of production subcontracting by industry groups over the years (Ajayi $[20,27]$ ). Whether in terms of number of contractors involved or volume of production subcontracting, textiles, wearing apparels and leather industry group dominates the productionsubcontracting scene. While the number of subcontractors engaged by any contracting firm ranged from one to a maximum of four, over fifty per cent of the contractors engaged the services of a maximum of two subcontractors. The number of subcontractors engaged varied markedly especially in food, beverages and tobacco; chemicals and pharmaceuticals and textiles, wearing apparel and leather industry groups (see Ajayi [20, 28]). The dominant form of subcontracting is speciality subcontracting mainly carried out by independent subcontractors over short distances. Production subcontracting became very important after the introduction of the Structural Adjustment Programme (SAP) 
in 1986, and it is perceived by industrialists as very important in reducing the costs of production.

The volume of production subcontracting defined in terms of the monetary values increased and varied significantly amongst the contracting firms over the years (see Ajayi $[20,25]$ for details). It is further shown that there is no significant relationship between the volume of production subcontracting and the size and structural characteristics of contracting firms. It is only in the motor vehicles and miscellananeous assembly industry group that production subcontracting accounted for more than thirty per cent of the total costs of production in any of the years. Textiles, wearing apparel and leather industry group accounted for the largest volume of production subcontracting in any of the years. While all the industry groups are involved in production subcontracting within the Lagos region, only five of the industry groups carried production subcontracting beyond the Lagos region.

Production subcontractors are concentrated in Lagos, Ikorodu, Sagamu and Ibadan in the Southwest; Jos, Kaduna, Zaria, Kano, and Sokoto in the north; and a few other locations such as Benin, Owerri, Port-Harcourt and Ilorin. For instance, in textiles, wearing apparel and leather industry group, spinnards and yarn are received from subcontractors in Ikorodu, Kano, Lagos, and Zaria, while tarpaulin materials are received from subcontractors in Zaria only (Ajayi [20]). The spatial distribution of production subcontracting activities is significantly explained by the number of industrial establishments in the various locations (see Ajayi [20,28] for details).

\subsection{Commercialization and privatization of industrial concerns}

A major aspect of globalization is commercialization and privatization of industrial concerns which literarily translates to the "transfer of government owned shareholding in designated enterprises to private shareholders, comprising individual and corporate bodies" (FRN [31]). In essence, the government has a restrictive role to play which simply is that of the maintenance of law and order (Ndebbio [33]). Privatization in Nigeria has its root in the economic liberalization decree of 1982 which later culminated in the issue of commercialization and privatization of public enterprises two years later. By 1986, the government announced its intension to divest government holdings in some public enterprises, especially the ailing parastatals. The Structural Adjustment Programme (SAP) then introduced has its integral part in "the rationalization and commercialization/privatization of public enterprises" (NES [34]).

In 1988, the policy thrust legalizing commercialization and privatization of Public Enterprises (PEs) now Bureau for Public Enterprises (BPE) was promulgated (Commercialization and Privatization Decree No. 25). Other industrial policy instruments include the New Industrial Policy of 1989 widely accredited as a replacement of the amended indigenization policy of 1977 to specifically encourage foreign investments and allowing indigenous businesses to benefit from the National Economic Reconstruction Fund-NERFUND (Ndebbio [35]), and the Nigerian Investment Promotion Decree No. 16 and the 
Foreign Exchange (Monitoring and Miscellaneous Provision) Decree No.17 of 1995. All these were directed at both indirect and direct investment in the Nigerian economy for improved productivity, growth and development. Nigeria has thus adopted the macro institutional approach to privatization through: lessening the dominance of unproductive investment in public sector; improving the sector's efficiency; intensifying the growth potential of the private sector; trimming down the size of the public sector; and contributing to the solution of the country's fiscal problem, etc.

Privatization of industrial concern in Nigeria has received little empirical investigation. For instance, Udeaja [36] has shown that although the two (insurance) firms investigated recorded significant increase in taxation after privatization, positive improvement in wage income, the share of wage income in the value-added of the firms and the share of workers' wages to the company's overall value-added. Perhaps, Onyeonoru [37], on globalization and industrial performance is instructive here. Most studies have analyzed the policy thrust of commercialization and privatization in Nigeria (see Obadan and Ayodele [38]; Oriakhi [39]; Odiase-Alegimenlen [40]; Okoh [41]). There is no known study that has succinctly analyzed the issue of privatization on the industrial sector of the Nigerian economy.

\section{Challenges in the new millennium}

Given the spate of industrial growth, it is hoped that the spatial pattern could change if industrialists adopt the strategy of industrial linkages, and especially production subcontracting which has become a driving force in contemporary industrial development strategy in the world today. The Japanese experience has shown that the promotion of industrial subcontracting in economic development is largely motivated by the participation of small entrepreneurs who are largely involved in production subcontracting - an industrial production strategy which can launch a developing economy like Nigeria into a world industrial nation. Such motivation could come in either of two forms. On the one hand is the encouragement of retirees to set up small business units' with the sole aim of producing parts or sub-assembly of products for large firms. On the other hand, the government is involved in the setting, and facilitating collaborative ventures between large and small-scale enterprises, especially in the hinterlands.

Indeed, Mabogunje [4]; Ajayi [20, 25-29]; and Abumere [42] have argued that production subcontracting is a major industrial strategy that could be used to launch Nigeria into the desired industrial nation. This is especially so given the nations privatization and commercialization policies, and the development of the Export Processing Zones (EPZs) in Lagos, Port Harcourt and Calabar. This will further encourage the local sourcing of industrial raw materials given the ongoing privatization and commercialization policies in the industrial development Nigeria. 


\section{References}

[1] Schatzl, L. (1973), Industrialization in Nigeria: A Spatial Analysis. Weltforum- Verlag. Munchen.

[2] Ayeni, B. (1981a), The Spatial Distribution of Manufacturing Industries in Nigeria. Technical Report No 2, Department of Geography, University of Ibadan, Ibadan, Nigeria.

[3] Ayeni, B. (1981b), Spatial Dimension of Manufacturing Activities in Nigeria. Technical Report, Department of Geography, University of Ibadan.

[4] Mabogunje, A. L. (1990), "Industrialisation within an Existing System of Cities in Nigeria". In Ayeni, B. and A. Faniran (eds), Geographical Perspectives on Nigeria's Development. Published by The Nigerian Geographical Association, Jumark (Nig) Ltd., Ibadan, Nigeria. pp 64-79.

[5] Onyemelukwe, J.O.C. (1983), "Structural and Locational Characteristics of Manufacturing". In: Oguntoyinbo, J.S., O.O. Areola, M. Filani (eds), A Geography of Nigerian Development. 2nd edition. Heinemann Educational Books (Nig) Ltd. Ibadan, Nigeria, pp. 296-310.

[6] Flint, J.E. (1960), Sir George Goldie and the Making of Nigeria, Oxford University Press.

[7] Aboyade, O. (1968), "Industrial Location and Development Policy: the Nigeria Case", Nigerian Journal of Economics and Social Studies, Vol. 10(3).

[8] Mabogunje, A.L. (1973), "Manufacturing and the Geography of Development in Tropical Africa" Economic Geography, Vol. 49, pp. 1-20.

[9] Adegbola, K. (1983), "Manufacturing Industries". In Oguntoyinbo J.S. (eds). A Geography of Nigerian Development, 2nd edition, Heinnemann Educational Books Ltd, Ibadan. pp. 326-338.

[10] Teriba, O; E.C. Edosien and M.O. Kayode (1981), "The Structure of the Nigerian Economy", In: Teriba, O; E.C. Edosien and M.O. Kayode, The Structure of Manufacturing Industry in Nigeria, University of Ibadan Press. Chapter 2, pp. 13-28.

[11] Teriba, O. and M.O. Kayode (1977), Issues in Industrialization. In: Teriba, O. and M. O. Kayode (eds), Industrial Development of Nigeria: Patterns, Problems and Prospects. Ibadan University Press, Ibadan, Nigeria.

[12] FOS (1979), Federal Office of Statistics: National Accounts of Nigeria, 1981-1994.

[13] Federal Ministry of Industries (1989), Manufacturing Industries in Nigeria, 1989.

[14] MAN (1983), Manufacturers' Association of Nigeria: Directory

[15] Corfrey, M. et al (1979), Rural Urban Migration in a Lewis-Model Context: The Manchester Journal, No 47.

[16] Nwafor, J. C. (1982), "Manufacturing I: Consumer Goods". In: Barbour, K. M. et al (eds), Nigeria in Maps, Nigeria Publishers Services Ltd., Ibadan, pp. 106-107. 
[17] Ukwu, I.U. (1994), "Industrialisation and Economic Development in Nigeria: the significance of the Structural Adjustment Programme". Nigerian Journal of Economic and Social Studies, 36(1, 2, 3), pp. 434-448.

[18] MAN (1983), Manufacturers' Association of Nigeria: Directory.

[19] Federal Republic of Nigeria (1990), First National Rolling Plan 1990-1992. National Planning Office, Federal Ministry of Budget and Planning, Lagos.

[20] Ajayi, D.D. (1998), Spatial Patterns of Production Subcontracting in Nigeria: a case study of the Lagos Region. Ph.D. Thesis, Department of Geography, University of Ibadan, 221pp.

[21] CBN (2003), Central Bank of Nigeria: Statistical Bulletin.

[22] Onyemelukwe, J.O.C. (1978), "Structural and Locational Characteristics of Manufacturing". In: Oguntoyinbo J.S et al (eds), A Geography of Nigerian Development, Heinemann Educational Books Ltd.

[23] Ajaegbu, H.I. (1976), Urban and Rural Development in Nigeria. London.

[24] Abiodun, J.O. and A.S. Aguda (1988), "The Distribution of Manufacturing Industries in Kwara state, Nigeria". Nigeria Geographical Journal, Vol. 30 and 31, (1\&2), pp.103-114.

[25] Ajayi, D.D. (2000), "The Determinants of the Volume of Production Subcontracting in Nigeria", Nigeria Journal of Economic and Social Studies (NJESS), Vol. 42(1): 95-111.

[26] Ajayi, D.D. (2001), "Industrial Subcontracting Linkages in the Lagos Region, Nigeria". The Nigerian Journal of Economic and Social Studies (NJESS), Vol. 43 (2): 265-277.

[27] Ajayi, D.D. (2002), "Temporal Pattern of Production Subcontracting in Nigeria", Annals of the Social Science Academy of Nigeria. Numbers 14 \& 15: 67-81.

[28] Ajayi, D.D. (2003a), "Nature and Scope of Production Subcontracting in Nigeria", Africa Development, Vol. XXVIII, Nos. 3 \& 4: 89-111.

[29] Ajayi, D.D. (2003b), "Spatial Pattern of Production Subcontracting in Nigeria", Research for Development Journal, Vol. 17 (1\&2), pp. 27-50.

[30] [30] Ajayi, D.D. (2004), "Growth Pattern and the Industrial Development of the Lagos Region, Nigeria”, Indonesian Journal of Geography, Vol. 36, Number 2, pp. 85-94.

[31] Federal Republic of Nigeria (1988), Ministry of Commerce Industries, Abuja.

[32] Ajayi, D.D. (2007), "Recent Trends and Patterns in Nigeria's Industrial Development", Africa Development, Volume. XXXII, Number 2, pp. 139155.

[33] Ndebbio, J.E.U. (2003), "Towards Privatization and Industrial Investment: Priorities for Sustainable Growth and Developments in Akwa-Ibom State of Nigeria", Nigerian Journal of Economics and Development Matters, Volume 1(1), pp. 45-60.

[34] Nigerian Economic Society (1988), Privatization of Public Enterprises in Nigeria, Proceedings of the 1988 One-Day Seminar.

[35] Ndebbio, J.E.U. (1997), "Towards and Industrial Investment: Priorities for Sustainable Growth and Developments in Akwa-Ibom State of Nigeria", 
Nigerian Journal of Economics and Development Matters, Volume 1 (1), pp. 45-60.

[36] Udeaja, A.E. (2003), "Evaluation of the Privatisation Performance: Evidence from the Privatised Insurance in Nigeria", Research for Development, Volume 19 (1\&2), pp.191-220.

[37] Onyeonoru, I. (2003), "Globalisation and Industrial Performance in Nigeria", Africa Development, Vol. XXVIII, Nos. 3 \& 4, pp. 36-66.

[38] Obadan, M.I. and A.S. Ayodele (1998), Commercialization and Privatization Policy in Nigeria. National Centre for Economic and Management Administration (NCEMA), Ibadan, Nigeria, 206 pages.

[39] Oriakhi, D.E. (2001), "Examining the Benefits of Privatization: the case of Nigeria", The Nigerian Economic and Financial Review, Vol. 6 (2), pp.7390 .

[40] Odiase-Alegimenlen, O.A. (2003), 'An Evaluation of the Objectives of the Current Privatization Exercise in Nigeria", Law. Social Justice and Global Development (An Electronic Law Journal), Issue 2, pp. 1-12.

[41] Okoh, R.N. (2004), "Global Integration and the Growth of Nigeria's NonOil Exports", Paper Presented at the African Conference, 21-22, March. Oxford, U.K.

[42] Abumere, S.I. (2002), "Industrial Linkages and Development in Nigeria". In: Aboyade, B. and S. Abumere (eds), Players in the Development Process: Essays in Honour of Murtala A. Adetunji. Fountain Publications Ltd, Ibadan. Chap. 10:205-230. 